\title{
STUDI KONSENTRASI GULA YANG TEPAT DALAM PEMBUATAN SIRUP BUAH KELUBI (Eleiodoxa conferta)
}

\author{
Rekka Melisa, S.TP( ${ }^{(1)}$, dan Hermiza Mardesci ${ }^{(2)}$ \\ ${ }^{(1)}$ Alumni Teknologi Pangan Faperta UNISI \\ ${ }^{(2)}$ Dosen Teknologi Pangan Faperta UNISI \\ mimzaaci@yahoo.co.id
}

\begin{abstract}
Abstrak
Tujuan penelitian ini adalah untuk mengetahui pengaruh konsentrasi gula terhadap mutu sirup buah kelubi yang dihasilkan. Dari hasil penelitian dapat ditarik kesimpulan, bahwa perlakuan terbaik terdapat pada D (larutan gula sukrosa $125 \% / \mathrm{bb}$ ) dengan kadar gula total $42.353 \%$, kandungan vitamin $\mathrm{C} 0.1183 \%$, total padatan terlarut $64.267 \mathrm{oBrix}$, dan $\mathrm{pH} 2.750 \%$. Pada pembuatan sirup asam kelubi dengan penambahan gula sukrosa $80 \%, 95 \%, 110 \%$ dan $125 \%$ belum menghasilkan sirup buah kelubi kadar gula dengan standar SNI.
\end{abstract}

Kata Kunci : Sirup, Buah Kelubi, Konsentrasi Gula

\section{PENDAHULUAN}

Kelubi (Eleiodoxa Conferta) merupakan tumbuhan yang telah dikenal oleh masyarakat Indonesia. Buah kelubi kurang dimanfaatkan masyarakat, dari segi penggunaannya hanya buah masaknya saja kadang-kadang dipakai sebagai pengganti buah asam untuk rempah-rempah sayur.

Di Kabupaten Indragiri Hilir buah kelubi belum dimanfaatkan secara optimal. Khususnya di Desa Simpang Kateman Kecamatan Pelangiran. Menurut para masyarakat setempat pohon buah kelubi tumbuh secara liar dihutan desa setempat. Sampai saat ini belum ada petani yang membudidayakan pohon kelubi secara massal. Pada pra penelitian penulis telah melakukan analisa kadar vit $\mathrm{C}$ pada buah kelubi yang belum diolah. Dan didapatkan hasil kadar vit C pada buah kelubi $0.32 \%$. Buah kelubi biasanya dibiarkan membusuk ditangkainya dan berjatuhan untuk itu perlu dilakukan pemanfaatan.
Salah satu cara penanganan buah kelubi, seperti diolah manisan, asinan, dan sirup.

Sirup didefinisikan sebagai larutan gula pekat (Sakarosa : High Fructose Syrup dan atau gula inverse lainnya) dengan atau tanpa penambahan bahan tambahan makanan yang diijinkan. Definisi sirup yang lain yaitu sejenis minuman ringan berupa larutan kental dengan cita rasa beraneka ragam, biasanya mempunyai kandungan gula minimal 65\%.( Menurut SNI (1994).

Bahan utama yang umum digunakan dalam pembuatan sirup adalah sari buah, gula sebagai pemanis, dan bahan penstabil (stabilizer). Bahan pemanis yang sering digunakan dalam pengolahan sirup adalah jenis gula sukrosa. Seperti yang telah diketahui, sukrosa sebagai bahan pemanis memilik kandungan kalori yang cukup tinggi yaitu 400 kalori dalam 100 gram bahan.

Konsumsi makanan dan minuman dengan kandungan gula tinggi secara berlebihan dan tanpa diimbangi asupan gizi lain dapat menimbulkan 
gangguan metabolisme dalam tubuh sehingga menyebabkan gangguan kesehatan (Usmiati dan Yuliani, 2004). Untuk itu konsentrasi penambahan gula dalam pembuatan sirup harus diperhatikan.

Melakukan penelitian studi pembuatan sirup Tamarillo (Kajian Perbandingan Buah dan Konsentrasi Gula), diperoleh perlakuan terbaik dengan perbandingan air : buah $(1: 2)$ dengan konsentrasi kadar gula sukrosa $80 \%$. Hasil organoleptik perlakuan terbaik dari segi rasa 4.8 (menyukai), warna 4.4 (menyukai) dan aroma 4.6 (menyukai). Kualitas kimia perlakuan terbaik telah sesuai dengan syarat mutu produk sirup menurut SNI yaitu total gula $71.73 \%$, viskositas $1.869 \mathrm{cps}$, total padatan terlarut $68.9 \mathrm{oBrix}$ dan total antosianin 1.96 ppm. (Pratama, dkk (2011).

Berdasarkan uraian di atas penulis akan menggunakan asam kelubi sebagai bahan utama dalam pembuatan sirup dengan penambahan gula sukrosa sebagai bahan pemanis. Tetapi belum diketahui berapa persentase yang tepat dalam penambahan gula sukrosa agar menghasilkan sirup yang manis, dengan kekentalan, warna dan rasa yang disukai panelis serta memenuhi standar. Maka dari itu akan dilakukan penelitian mengenai "Studi Konsentrasi Gula yang Tepat dalam Pembuatan Sirup Buah Kelubi (Eleiodoxa conferta)".

\section{Tujuan Penelitian}

Tujuan penelitian ini adalah untuk mengetahui pengaruh konsentrasi gula terhadap mutu sirup yang dihasilkan.

\section{Manfaat Penelitian}

Manfaat penelitian ini adalah :

1. Memberikan alternatif kepada masyarakat untuk mengolah buah kelubi yang belum banyak dimanfaatkan menjadi suatu produk yang bermanfaat dan menjadi nilai ekonomi yang tinggi.

2. Sebagai informasi kepada masyrakat cara pembuatan sirup buah kelubi.

\section{METODOLOGI PENELITIAN}

\section{Bahan}

Bahan yang digunakan di dalam penelitian ini adalah kelubi matang, bahan pengental (CMC) dan air. Bahan untuk analisa kimia yaitu, etahanol, larutan $\mathrm{Pb}$-asetat, larutan $\mathrm{Na}_{2} \mathrm{HPO} 4$, larutan $\mathrm{NaOH}_{4} \mathrm{~N}, \quad \mathrm{H}_{2} \mathrm{SO}_{4} 6 \mathrm{~N}, \quad \mathrm{Na}_{2} \mathrm{~S}_{2} \mathrm{O} 3$ $0,1 \mathrm{~N}, \mathrm{Hcl} 4 \mathrm{~N}$, KI 30\%, methyl orange, isopentanol, air aquades, $\mathrm{NaOH} 0,1 \mathrm{~N}$. Larutan iod 0,01 $\mathrm{N}$ dan asam askorbat.

\section{Alat}

Alat yang digunakan di dalam penelitian ini adalah timbangan analitik, timbangan, gelas ukur, pengaduk kayu, corong, panci, pisau, baskom, kompor, botol, kain saring, alat untuk menutup botol, beaker glass, dan viskometer.

\section{Metode Penelitian}

Rancangan percobaan yang digunakan di dalam penelitian ini adalah Rancangan Acak Lengkap (RAL) dengan perlakuan perbandingan konsentrasi gula dan sari buah kelubi terdiri dari empat perlakuan yaitu :

$\mathrm{A}=80 \%$ Gula Sukrosa/berat bahan (450 gr)

$\mathrm{B}=95 \%$ Gula Sukrosa/berat bahan (450 gr)

$\mathrm{C}=110 \%$ Gula Sukrosa/berat bahan (450 gr)

$\mathrm{D}=125 \%$ Gula Sukrosa/berat bahan (450 gr)

Perlakuan ini diulang sebanyak 3 kali sehingga diperoleh pula perlakuan 4 x 3 dengan jumlah 12 satuan unit 
percobaan. Model rancangan yang digunakan adalah sebagai berikut :

$\mathrm{Y} i \mathrm{j}=\mu+\mathrm{Pi}+\mathrm{Eij}$

Di mana :

Y ij : Hasil pengamatan terhadap jumlah gula sukrosa (1-3)

$\mu \quad$ : Rata-rata

$\mathrm{Pi}$ : Pengaruh jumlah konsentrasi gula

E : Pengaruh sisa pada satuan percobaan yang mendapatkan perlakuan jumlah konsentrasi gula (1-3) pada ulangan (1-3)

I : Perlakuan jumlah gula Sukrosa (1-3)

J : Ulangan (1-3)

Hasil data dianalisa secara statistik, jika $\mathrm{F}$ hitung > dari $\mathrm{F}$ tabel, maka dilakukan uji lanjut BNJ taraf nyata $5 \%$.

\section{HASIL DAN PEMBAHASAN}

\section{Kadar Gula}

Kadar gula pada sirup adalah kadar sukrosa pada sirup berkisar antara $64 \%$ - 66\%. Hasil sidik ragam dari perlakuan penambahan gula pada pembuatan sirup buah kelubi berbeada nyata pada taraf $5 \%$ terhadap kadar gula (Lampiran 3). Rata-rata pengaruh penambahan gula terhadap kadar gula sirup buah kelubi yang dihasilkan setelah uji lanjut dilakukan dapat dilihat pada Tabel 1.

Tabel 1. Rata-rata Penilaian Kadar Gula terhadap Sirup Buah Kelubi.

\begin{tabular}{|c|r|}
\hline \multicolumn{1}{|c|}{ Perlakuan } & \multicolumn{1}{|c|}{ Rata-rata (\%) } \\
\hline $\mathrm{D}=125 \%$ Gula Sukrosa/berat bahan & $42.353 \mathrm{a}$ \\
$\mathrm{C}=110 \%$ Gula Sukrosa/berat bahan & $38.470 \mathrm{ab}$ \\
$\mathrm{B}=95 \%$ Gula Sukrosa/berat bahan & $32.729 \mathrm{~b}$ \\
$\mathrm{~A}=80 \%$ Gula Sukrosa/berat bahan & $23.364 \mathrm{c}$ \\
\hline
\end{tabular}

Keterangan : Angka-angka yang diikuti oleh huruf dan pada kolom yang sama berarti berbeda tidak nyata menurut uji Duncan taraf 5\%.

Dari hasil Analisa sidik ragam menunjukkan bahwa kadar gula dalam sirup buah kelubi berkisar antara $23.36 \%$ - $42.35 \%$ Kandungan gula tertinggi terdapat pada perlakuan D (Larutan gula sukrosa $125 \% / \mathrm{bb}$ ) dengan nilai $42.353 \%$ dan terendah pada perlakuan A (Larutan gula sukrosa $80 \% / \mathrm{bb}$ ) dengan nilai $23.364 \%$. Jadi semakin besar konsentrasi sukrosa dan semakin kecil konsentrasi sari buah kelubi yang ditambahkan, maka kandungan gula dalam bahan akan semakin meningkat. Menurut Suhardi dan Tranggono, ddk (1990) besarnya gula yang ditambahkan dalam bentuk monosakarida (glukosa, fruktosa) dan disakarida (sukrosa) akan menentukan kemanisan buah-buahan tersebut. Pendidihan larutan sukrosa dengan adanya kandungan asam yang terdapat pada buah maka akan terjadi proses hidrolisis yang menghasilkan kadar gula.

Menurut Standar Nasional Indonesia (SNI) 01-3544-1994, kandungan gula sirup min $65 \%$, dengan kadar gula yang tinggi sirup akan lebih awet sesuai dengan sifat dan fungsi gula yaitu sebagai bahan pengawet jika penggunaannya dalam konsentrasi tinggi. Untuk memenuhi syarat mutu tersebut, jumlah gula yang ditambahkan dalam proses pengolahan harus cukup besar, sehingga kadar gulanya cukup tinggi. Hasil percobaan menunjukkan bahwa sirup buah kelubi yang dihasilkan belum memenuhi standar yang telah ditetapkan SNI tahun 1994. 


\section{Kandungan Vitamin C}

Vitamin $\mathrm{C}$ tergolong vitamin yang mudah larut dalam air. Vitamin $\mathrm{C}$ atau asam L-askorbat adalah lakton, yaitu ester dalam asam hidroksikarboksilat dan diberi ciri oleh gugus enadiol yang menjadikan senyawa pereduksi yang kuat. Hasil sidik ragam dari perlakuan penambahan gula pada pembuatan sirup buah kelubi berbeda tidak nyata pada taraf $5 \%$ terhadap kandungan vitamin C. Rata-rata pengaruh penambahan gula terhadap kandungan vitamin $\mathrm{C}$ pada sirup buah kelubi yang dihasilkan setelah uji lanjut dilakukan dapat dilihat pada Tabel 2.

Tabel 2. Rata-rata Penilaian Vitamin C terhadap Sirup Buah Kelubi.

\begin{tabular}{|l|l|}
\hline \multicolumn{1}{|c|}{ Perlakuan } & Rata-rata (\%) \\
\hline $\mathrm{A}=80 \%$ Gula Sukrosa/berat bahan & 0.1500 \\
$\mathrm{~B}=95 \%$ Gula Sukrosa/berat bahan & 0.1309 \\
$\mathrm{C}=110 \%$ Gula Sukrosa/berat bahan & 0.1225 \\
$\mathrm{D}=125 \%$ Gula Sukrosa/berat bahan & 0.1183 \\
\hline
\end{tabular}

Dari hasil analisa sidik ragam menujukkan kandungan vitamin $\mathrm{C}$ pada sirup buah kelubi berkisar antara $0.11 \%$ - $0.15 \%$, dari hasil uji lanjut untuk semua perlakuan berbeda tidak nyata. Penurunan kandungan vitamin $\mathrm{C}$ buah kelubi telah diolah menjadi sirup, karena akibat dari proses lama pemasakan atau pemanasan, sesuai dengan pendapat Andarwulan dan Koswara (1992) bahwa pengaruh cara memasak (pengukusan atau perebusan) termasuk cara pemotongan dan volome air yang digunakan serta suhu berpengaruh terhadap vitamin $\mathrm{C}$.

Pada saat proses pemanasan kandungan vitamin $\mathrm{C}$ tidak tahan terhadap panas dan mudah teroksidasi. Asam askorbat dan garam natriumnya sangat stabil dalam keadaan tanpa air, tetapi dalam keadaan ada air dan oksigen atau bahan pengoksidasi lainnya maka asam askorbat menjadi sangat labil (Satuhu, 1994).

Selain itu, pemanasan selama pengolahan dapat menyebabkan terjadinya degradasi vitamin C. Hal ini disebabkan panas dapat mempercepat terjadinya oksidasi vitamin C. Menurut Winarno (1997), vitamin C mudah teroksidasi dan proses tersebut dipercepat oleh panas, sinar, alkali, enzim, oksidator serta oleh katalis tembaga dan besi. Pada proses pengolahan pangan, kehilangan vitamin C akibat reaksi enzimatis jumlahnya sangat sedikit, sedangkan reaksi non enzimatis menjadi penyebab utama hilangnya vitamin C (Wong, 1989). Vitamin $\mathrm{C}$ tergolong vitamin yang mudah larut dalam air. Vitamin $\mathrm{C}$ atau asam L-askorbat adalah lakton, yaitu ester dalam asam hidroksikarboksilat dan diberi ciri oleh gugus enadiol yang menjadikan senyawa pereduksi yang kuat. Asam L-askorbat mudah teroksidasi secara reversibel menjadi asam L-dehidroaskorbat yang masih mempunyai keaktifan sebagai vitamin $\mathrm{C}$ (Deman, 1997). Asam dehidroaskorbat secara kimia sangat labil dan dapat mengalami perubahan lebih lanjut menjadi asam L-diketogulonat yang tidak memiliki keaktifan vitamin C. Asam L-diketogulonat yang teroksidasi akan membentuk asam oksalat dan asam L-treonat (Winarno, 1997).

\section{Total Padatan Terlarut}

Uji total padatan terlarut ini dilakukan untuk mengetahui kadar gula pada sirup. Tujuan analisa ini adalah 
untuk mengetahui kadar gula pada sirup yang sesuai dengan SNI. Pengukuran ini dilakukan dengan cara meneteskan produk (sirup) pada kaca sensor yang ada pada hand refraktometer dan angka brix dapat segera dibaca.

Hasil sidik ragam dari perlakuan penambahan gula pada sirup buah kelubi berbeda nyata pada taraf 5\% terhadap total padatan terlarut. Rata-rata pengaruh penambahan gula terhadap total padatan terlarut sirup buah kelubi yang dihasilkan setelah uji lanjut dilakukan dapat dilihat Tabel 3.

Tabel 3. Rata-rata Penilaian Padatan Terlarut terhadap Sirup Buah Kelubi.

\begin{tabular}{|c|r|}
\hline \multicolumn{1}{|c|}{ Perlakuan } & \multicolumn{2}{|c|}{ Rata-rata (\%) } \\
\hline $\mathrm{D}=125 \%$ Gula Sukrosa/berat bahan & $64.267 \mathrm{a}$ \\
$\mathrm{C}=110 \%$ Gula Sukrosa/berat bahan & $58.667 \mathrm{~b}$ \\
$\mathrm{~B}=95 \%$ Gula Sukrosa/berat bahan & $56.000 \mathrm{~b}$ \\
$\mathrm{~A}=80 \%$ Gula Sukrosa/berat bahan & $51.800 \mathrm{c}$ \\
\hline
\end{tabular}

Keterangan : Angka-angka yang diikuti oleh huruf dan pada kolom yang sama berarti berbeda tidak nyata menurut uji Duncan taraf 5\%.

Dari hasil analisa sidik ragam menunjukkan total padatan terlarut berkisar antara $51.80 \mathrm{oBrix} \quad-$ 64.267oBrix, dengan total padatan terlarut paling tinggi pada perlakuan D (Larutan gula sukrosa $125 \% / \mathrm{bb}$ ) sebesar 64.267oBrix dan terendah pada perlakuan A (Larutan gula sukrosa $80 \% / \mathrm{bb}$ ) sebesar 51.80 oBrix. Jadi semakin tinggi kandungan gula, maka total padatan terlarut juga tinggi. Hal ini disebabkan, kenaikkan total padatan terlarut pada buah-buahan akibat terbentuknya gula-gula sederhana hasil degradasi pada fase kemasakkan (Pantastico, 1993).

Menurut (Munafi, 2004), komponen-komponen yang terukur sebagai total padatan terlarut yaitu sukrosa, gula pereduksi, asam organik, dan protein. Mukarromah dkk. (2010), menyatakan bahwa total padatan terlarut yang tinggi disertai dengan asam yang tinggi ( $\mathrm{pH}$ rendah) pada sirup maka dapat dikatakan bahwa hal ini merupakan teknik pengawetan pangan.

\section{Derajat Keasamaan (pH) Sirup}

Derajat keasamaan $\mathrm{pH}$ digunakan untuk menyatakan tingkat keasamaan basa yang dimiliki oleh zat, larutan atau benda. $\mathrm{pH}$ normal berkisar 7 nilai $\mathrm{ph}>7$ menunjukkan basa dan $\mathrm{pH}<7$ menunjukkan asam.

Hasil sidik ragam dari perlakuan penambahan gula pada pembuatan sirup buah kelubi berbeda nyata pada taraf 5\% terhadap kadar $\mathrm{pH}$ sirup. Rata-rata pengaruh penambahan gula terhadap $\mathrm{pH}$ sirup buah kelubi yang dihasilkan setelah uji lanjut dilakukan dapat dilihat pada Tabel 4. 
Tabel 4. Rata-rata Penilaian Derajat Keasaman (pH) terhadap Sirup Buah Kelubi.

\begin{tabular}{|l|r|}
\hline \multicolumn{1}{|c|}{ Perlakuan } & \multicolumn{1}{|c|}{ Rata-rata } \\
\hline $\mathrm{D}=125 \%$ Gula Sukrosa/berat bahan & $2.7500 \mathrm{a}$ \\
$\mathrm{C}=110 \%$ Gula Sukrosa/berat bahan & $2.7433 \mathrm{a}$ \\
$\mathrm{B}=95 \%$ Gula Sukrosa/berat bahan & $2.7233 \mathrm{~b}$ \\
$\mathrm{~A}=80 \%$ Gula Sukrosa/berat bahan & $2.7067 \quad \mathrm{c}$ \\
\hline Keterangan $:$ Angka-angka yang diikuti oleh huruf dan pada kolom yang sama berarti berbeda \\
\end{tabular}

Dari hasil analisa sidik ragam menunjukkan $\mathrm{pH}$ sirup berkisar antara 2.70 - 2.75. Perlakuan terbaik pada perlakuan A (Larutan gula sukrosa $80 \% / \mathrm{bb})$ sebesar 2.70. Hal ini sesuai dengan pendapat Astawan (1991) bahwa $\mathrm{pH}$ produk minuman dari buah-buahan sebaiknya diatur pada level asam, untuk mencegah perkembangan bakteri atau cendawan maupun khamir yang hidup dalam suasana asam. Di samping itu juga untuk menimbulkan cita rasa yang lebih segar.

Asam dapat mempertegas rasa karena asam dapat mengintensifkan penerimaan rasa-rasa lain. Unsur yang menyebabkan rasa asam adalah ion $\mathrm{H}+$ atau ion hidrogenium $\mathrm{H} 3 \mathrm{O}+$ (Winarno, 1997).

\section{KESIMPULAN}

Dari hasil penelitian diatas dapat ditarik kesimpulan, bahwa perlakuan terbaik terdapat pada D (larutan gula sukrosa $125 \% / \mathrm{bb}$ ) dengan kadar gula total $42.353 \%$, kandungan vitamin $\mathrm{C}$ $0.1183 \%$, total padatan terlarut 64.267oBrix, dan $\mathrm{pH} 2.750 \%$. Pada pembuatan sirup asam kelubi dengan penambahan gula sukrosa $80 \%$, 95\%, $110 \%$ dan $125 \%$ belum menghasilkan sirup buah kelubi kadar gula dengan standar SNI.

\section{SARAN}

Pada pembuatan sirup asam kelubi dengan penambahan gula sukrosa
$80 \%, 95 \%, 110 \%$ dan $125 \%$ belum menghasilkan sirup buah kelubi kadar gula reduksi dengan standar SNI. Sehingga perlu adanya penelitian lanjutan dengan menggunakan konsentrasi gula yang lebih tinggi.

\section{DAFTAR PUSTAKA}

Andarwulan, N. Dan S, Koswara, 1992. Kimia Vitamin. Rajawali Pres, Jakarta.

AOAC Assosiation of Official Analytical Chermist, 2005. Official Method of Analysis of The Assosiation of Official Analytical of Chermist. Arlington : The Assosiation of Official Analytical Chermist, inc.

Aprianti, L. 2009. Pengawetan yang Aman. Fakultas Kedokteran USU. Medan.

Astawan, M., 1991. Teknologi Pengolahan Pangan Nabati. Tepat Guna. Akademi.Pressido, Jakarta.

Bielig, Hans. J., dan Joachim Werner., 1986. Fruit Juice Processing. FAO Agriculturallllll Services Bulletin. Roma.

Buckle, K.A, Edwards, R.A, Fleet, G.H dan Wotton, M. 1987. Ilmu Pangan. Terjemahan Purnomo, $\mathrm{H}$ dan Aidon. UI Press, Jakarta.

Deman, John. M. 1997. Kimia Makanan. Terjemahan Kosasih Padmawinata. Penerbit ITB. Bandung.

Dewan Standarisasi Nasional. 1994. Sni Sirup (SNI 01-3544-1994). 
Dewan Standarisasi Nasional, Jakarta.

Deman, J, M.1980. Kimia Makanan.

Penerjemah : K, Padmawinata.

ITB : Bandung.

Gagung, J dan Sunarto., 2010. Pengaruh

Konsentrasi Gula terhadap

karakteristik Sirup Buah Naga.

Jurnal Teknologi Pangan.

Universitas Malang.

Herlina, ddk., 2007. Pengaruh

Penggunaan Jenis Gula dan

Konsentrasi Saribuah Terhadap

Beberapa Karakteristik Sirup

Jeruk Keprok Garut (Citrus

Nobilis Lour). Fakultas

Teknologi Industri Pertanian.

Universitas Padjadjaran.

Herliza.2013. Pengaruh Persentasi Gula

Kelapa dan Perbandingan Tepung

Ketan dengan Pisang Muli terhadap Mutu Dodol

Pisang.Tembilahan :Universitas Islam Indragiri.

Haryoto., 1998. Sirup Jahe. Kanisius. Yogyakarta.

Hasdin, 2011. Asam Paya. http://mykampong-

hasdin.blogspot.com. Diakses tanggal 20 Januari 2015.

Jagtiani, j., Chan, H. T. And sakai, W.S. 1988. Tropical Fruit Processing, Academic Press, San Diego.

Jacobs, M.B. 1984. The Chemical Analysis of Food and Food Products. D Van Nostrand Co. Inc. London.

Kusnandar, dkk, 2008. Teknologi Proses Produksi Minuman Nata de Coco dalam Cup. www.unhas.ac.id. Diakses tanggal 20 januari 2015.

Lutony, Tony. L., 1993. Tanaman Sumber Pemanis. PT. Penebar Swadaya. Jakarta.

Marta, H, dkk., 2007. Pengaruh Pengunaan Jenis Gula dan Konsentrasi Saribuah terhadap beberapa Karakteristik Sirup

Jeruk Keprok Garut (Citrus nobilis Lour). Laporan Penelitian. Pakultas Teknologi Industri Pertanian Universitas Padjadjaran.

Muafi, K. 2004. Produksi Asam Asetat Kasar dari Jerami Nangka. Skripsi Fakulta Teknologi Pertanian. Universitas Brawijaya. Malang.

Mukaromah, U, S, H. Susetyorini dan S. Aminah. 2010. Kadar Vitamin C, Mutu Fisik, pH dan Mutu Organoleptik Sirup Rosella (Hibiscus Sabdariffa, I) Berdasarkan Cara Ekstraksi. Jurnal Pangan dan Gizi Vol.I (01): 43-51.

Pratama, S.B., Susinggih. W., Arie. F., 2011. Studi Pembuatan Sirup Tamarillo (Kajian Perbandingan Buah dan Konsentrasi Gula). Jurnal Industria Vol 1 No 3 hal 180 - 193. Teknologi Industri Pertanian Fakultas Teknologi Pertanian Universitas Brawijaya.

Pantastico, E, R, B, 1993. Fisiologi Pasca Panen, Penanganan dan Pemanfaatan Buah-buahan dan sayuran Tropika dan Subtropika. Terjemahan Komeriyani. UGM Press Yogyakarta.

Safari, A.1995. Teknik Membuat Gula Aren. Kanisius. Yogyakarta.

Satuhu, S., 1994. Penanganan dan Pengolahan Buah. PT. Penebar Swadaya. Jakarta.

Sudarmadji S, Haryono B, \& Suhardi., 1997. Prosedur Analisa untuk Bahan Makanan dan Pertanian. Penerbit Liberty, Yogyakarta.

SNI Standar Nasional Indonesia. 0131440. 2005. Gula Kristal Putih. Jakarta: Badan Standarisasi. 
Tranggono dan Suhardi, 1990. Biokimia dan Teknologi Pasca Panen. Pusat antar Universitas Pangan dan Gizi. Gadjah Mada University Press, Yogyakarta.

Tressler, D.K. and M.A. Joslyn., 1961. Fruit and Vegetable Juice Processing Technology. The AVI Pubblishing Company, Inc., Westport, Connecticut.

Usmiati S dan Yuliani S., 2004. Pemanis Alami dan Buatan untuk Kesehatan . Warta Penelitian dan Pengembangan Tanaman Industri 10 (1) : $13-17$.
Wong, Dominic, W.S., 1989. Mechanism And Theory In Food Chemistry. Van Nostrand Reinhold. New York.

Winarno, F.G. 1997. Kimia Pangan dan Gizi. PT Gramedia Pustaka Utama. Jakarta.

Winarno, F.G., 2000. Kimia Pangaan dan Gizi. PT. Gramedia Pustaka Utama.

Winarno, F.G. 2008. Kimia Pangan dan Gizi. Jakarta: PT.Gramelia.

Winarno, F.G. 2004. Keamanan Pangan Jilid 1. Bogor: M-Brio Press. 